\title{
İleri yaşta saptanan nadir yerleşimli anterior trakeal timik kist olgusu
}

\author{
Rare localized anterior tracheal thymic cyst case in geriatric age
}

\author{
Celal Bugra SEZEN¹, Ali CELİK², Anar SULEYMANOV², Anıl GOKCE², Abdullah Irfan TASTEPE ${ }^{2}$
}

${ }^{1} Y$ edikule Chest Diseases and Thoracic Surgery Training and Research Hospital, Department of Thoracic Surgery, Istanbul/Turkey 2Gazi University School of Medicine, Department of Thoracic Surgery, Ankara/Turkey.

\begin{abstract}
The thymic cysts are uncommon lessions. The mediastinal thymic cysts are frequently seen in anterior mediastinum. Anterior tracheal thymic cysts can be infrequently identified. The 70 years old woman was administrated to hospital with dyspnea complain. After the analysis of the patient, $40 * 38 \mathrm{~mm}$ dimension cysts was detected at anterior tracheal area. The patient went through surgery using cervical incision and $4 \mathrm{~cm}$ dimension cystic lession is totally excised from anterior trachea. The pathological examination was reported as thymic cysts. We discussed the thymic cyst case showing uncommon settlement in the context of literature.

Key words: Thymic Cyst, Mediastinal Cysts, Paratracheal Thymic Cyst

\section{öz}

Mediastinal timik kistler nadir olarak görülen lezyonlardır. Mediastinal timik kistler sıklıkla anterior mediastende yer almaktadır. Anterior trakeal timik kistler ise oldukça nadir olarak tanımlanmıştır. 70 yaş kadın hasta nefes darlığı şikayeti ile hastaneye başvurmuştur. Hastanın yapılan tetkiklerinde anterior trakeal alanda yerleşimli yaklaşık 40x38mm boyutlarında kistik lezyon saptanmıştır. Hasta servikal kesi ile operasyona alınmıştır. Trakeanın anteriorunda yaklaşık 4 cm'lik kistik lezyon total olarak eksize edilmiştir. Hastanın patolojisi timik kist olarak raporlanmıştır. Bizde nadir yerleşim gösteren bu timik kist olgusunu literatür eşliğinde değerlendirdik.
\end{abstract}

Anahtar Kelimeler: Timik Kist, Mediastinal Kist, Paratrakeal Timik Kist

\section{Introduction}

Mediastinal thymic cysts are rarely seen lesions. They constitute $1-2 \%$ of all mediastinal cysts (1). Mediastinal thymic cysts are often localized at anterior mediastinum, but they can also develop, although rarely, from any region between the cervical area and the diaphragm. Anterior tracheal thymic cysts are much more atypically located cysts. We presented this case where an atypically located cyst in the geriatric age group was resected.

\section{Case Report}

A 70-year-old female patient presented to an external facility complaining about shortness of breath. Her lung x-ray taken after her physical examinations revealed a radiodense lesion in her anterior tracheal area. The patient was referred to our clinic for advanced examinations. In her computerized thoracic tomography, a cystic lesion approximately $40 \times 38 \mathrm{~mm}$ in size was seen in her anterior of tracheal region (Figure 1). The pa-

Corresponding Authora: Celal Buğra Sezen, Yedikule Chest Diseases and Thoracic Surgery Training and Research Hospital, Department of Thoracic Surgery, Istanbul/Turkey

E-mail: bugrasezen@hotmail.com

Received 21.06.2017 accepted 16.08.2017

Doi: $10.18663 / \mathrm{tjcl} .322919$ 
tient was taken to the operation room for a cervical collar incision. A cystic lesion of about $4 \mathrm{~cm}$ was found at lateral trachea during the operation (Figure 2). The cystic lesion was resected together with the soft tissues surrounding it. The cyst was excised without being ruptured. The patient was discharged without any problems on the second day following the operation. The patient's pathology was reported as thymic cyst. The patient was followed 28 month without and any recurrence.

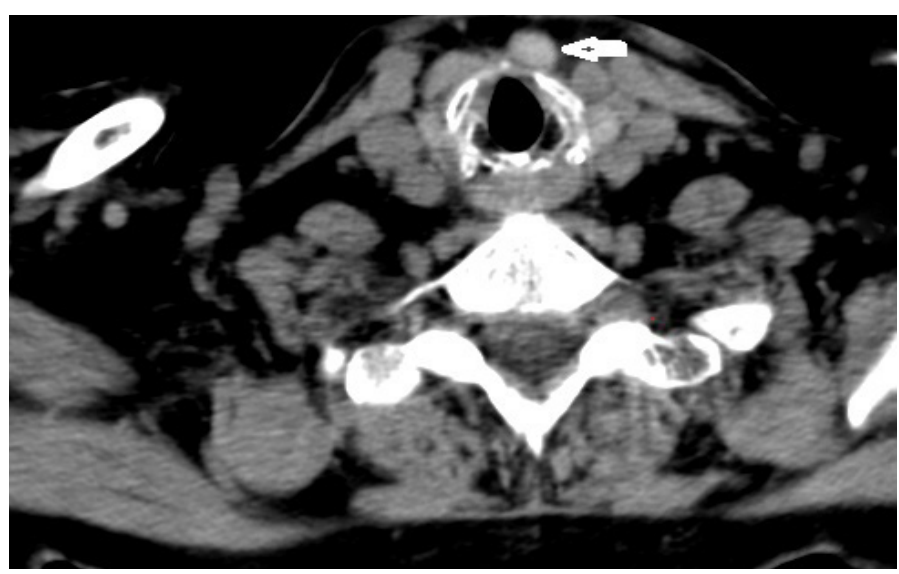

Figure 1. Thorax CT: A cystic lesion approximately $40 \times 38 \mathrm{~mm}$ in size was seen in right side of thyroid gland.

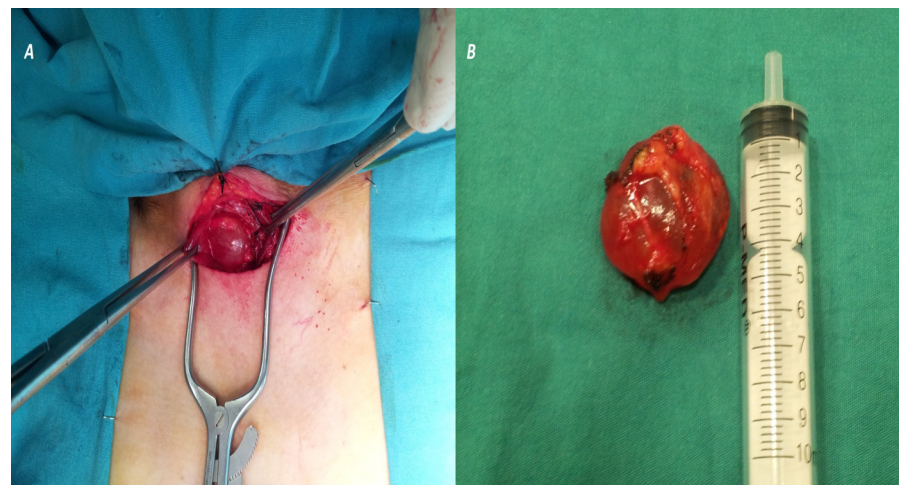

Figure 2. (A)Intraoperative image of paratracheal thymic cyst. (B)Excision image of paratracheal thymic cyst.

\section{Discussion}

Although the development of thymic cysts is not fully known, degenerative changes occurring in Hassal corpuscles are thought to cause the formation of such cysts (2).

Thymic cysts were first defined by Lieutaud in 1832 They can be seen in all age groups (3). Graeber et al. (4) reported in their study that the age interval of patients with these cysts was between 4 and 52 (mean 21.5 years). Cervical thymic cysts, on the other hand, are seen mostly in the pediatric age group, often occurring on the left side. However, they can also be seen rarely at advanced ages. Michalopoulos et al. (4) have reported that there are 35 cervical cyst cases in adults in the English literature between 1960 and 2011. They found 2 cases where excision was applied in the geriat- ric age group. Our case is the only thymic cyst case in which excision was used by way of collar incision in the geriatric age group. Thymic cysts are often seen in cervical and mediastinal regions. They are usually asymptomatic, but cervicomediastinal located cysts are symptomatic at a rate of $60 \%$ (2). Growth of these cysts leads to pressure complaints. Although the symptoms vary, complaints such as dyspnea, cough, chest pain and dysphagia are commonly seen. Our patient had shortness of breath associated with pressure. Swellings causing fluctuations in the cervical region are felt during the physical examinations of these patients. However, in swellings in the neck area, cystic hygroma, lymphangioma, teratoma, neurogenic cysts, vascular malformations, lung hernia and brachial cleft cysts should also be considered for a differential diagnosis (2). Although our patient had a shortness of breath, we did not find any other peculiarities in her examination.

Being often asymptomatic, thymic cysts are incidentally detected in a lung x-ray. Ultrasound, computerized tomography, magnetic resonance imaging methods are used for the diagnosis. An oval, well-circumscribed lesion with a homogenously distributed fluid inside as seen in the BT helps recognize the cyst (6). The lesion in our case was also well-circumscribed and had a homogenously distributed fluid inside.

Surgical removal of thymic cysts is the most preferred method. The surgical methods used include thoracotomy, sternotomy and videothoracoscopic removal of the cyst. Since the cyst was localized at the cervical region in our case, we preferred excision with cervical collar incision.

\section{Conclusion}

Tymic cysts should also be considered for differential diagnosis in lumps localized at anterior mediastinal regions. Since there is the risk of malignity, albeit low, in tymic cysts, the treatment approach preferred is total excision.

\section{Declaration of Conflict of Interest}

No conflict of interest has been reported in this paper.

\section{References:}

1. Cigliano B et al. "Cervical thymic cysts." Pediatric Surg Intern 2007: 1219-1225.

2. Rieker RJ, Aulmann S, Schnabel PA et al. Cystic thymoma. Pathol Oncol Res 2005: 11; 57-60

3. Kostrzewski P, Rewicka D, Karolczak M. Cervical thymic cyst. Polish Journal of Surgery 2007: 228-31.

4. Michalopoulos N, Papavramidis TS, Karayannopoulou et al. Cervical Thymic Cysts in Adults vol. 2011: 21; 6-11

5. Faculty IM, Surgery P, Faculty GM, Case Reports Cervicomediastinal Thymic Cyst : Report of a Case 2005: 1070-72

6. Tomiyama N, Honda O, Tsubamoto M, Inoue A. Anterior mediastinal tumors: Diagnostic cccuracy of CT and MRI. European Journal of Radiology 2009: 280-88 